\title{
Race of new inorganic materials towards an ultra neolithic age
}

\begin{abstract}
A K CHATTERJEE
The Associated Cement Cos. Limited, Research and Consultancy Directorate, L.B.S. Marg, Thane 400604 , India

Abstract. Three generally accepted generic groups of competitive engineering materialsmetals, inorganic ceramics, as well as plastics and polymers belonging to the organic familyhave been comparatively reviewed in the context of raw materials availability, energy requirements in production, engineering properties, combustibility and environmental friendliness. The intrinsic advantages of inorganic materials have been discussed. The shortcomings of engineering properties of inorganic materials and the new technologies of making chemically bonded ceramics or biomimic compounds from inorganic materials with improved toughness have been dealt with. The expanding application horizons of inorganic materials have been illustrated with the help of several novel products.
\end{abstract}

Keywords. Inorganic materials; ceramics; biomimic compounds.

\section{Introduction}

The development of mankind from primitive and nomadic state to the technologically complicated way in which we live today is a gradual but spectacular progress. It is well known that this march of human civilization has an intimate man-material relationship spanning over two million years at least. The role that materials have played in this progress of mankind has been confirmed by archeologists by distinguishing time spans by the name of materials that are characteristic for these eras. Thus, today, we frequently make reference to paleolithic, mesolithic, neolithic, chalcolithic, bronze and iron ages. Of these, the last two spanning over say 5000 years have been remarkably innovative as man could hit upon a host of synthetic materials like metals on the one hand and bricks, lime-pozzolana cements, gypsum binders and glass-all of inorganic origin-on the other.

In fact, all these products dominated our technology scenario until the early years of the century. Then came the age of plastics with Baekeland producing the first synthetic resin Bakelite in 1907, followed by the appearance of synthetic rubber in 1910 , polystyrene in 1925 , nylon, polythene and polyesters in 1930 s.

The present times are, therefore, witnessing an interesting race of three broadly distinguishable man-made materials: organic, inorganic and metallic. The competitive advantage of each class of these materials is decided in the context of (i) raw materials availability, (ii) energy requirement in production, (iii) engineering properties, (iv) combustibility and (v) environment-friendly disposability. The present article is an attempt to evaluate the relative preference for inorganic materials, based on the above criteria, vis-a-vis the other two families of materials, on its own as well as in the form of composites. 
Table 1. Main constituent elements of igneous rocks in the Earth's crust.

\begin{tabular}{lr}
\hline Elements & Wt.\% \\
\hline $\mathrm{O}$ & 46.42 \\
$\mathrm{Si}$ & 27.59 \\
$\mathrm{Al}$ & 8.08 \\
$\mathrm{Fe}$ & 508 \\
$\mathrm{La}$ & 3.61 \\
$\mathrm{Na}$ & 2.83 \\
$\mathrm{~K}$ & 2.58 \\
$\mathrm{Mg}$ & 2.09 \\
\hline
\end{tabular}

\section{Raw materials availability}

Geologically speaking, the Earth's crust is divided into the following segments from top downwards (Rankama and Sahama 1964),

Sial:silicon-aluminium

Sialma:silicon-aluminium-magnesium

Sima:silicon-magnesium.

As indicated above, each segment owes its name to the predominantly constituent elements in them. The eight main constituents of the crust as reflected in the analysis of igneous rocks are listed in table 1 .

It is evident that the most abundant elements after oxygen are silicon and aluminium. Iron comes later and other metals like copper and zinc do not appear in the list of the first eight elements.

It might be interesting to compare the above scenario with the raw material requirement for plastics and polymers. As mentioned already, the synthetic polymer industry was well established by 1940, when it was claimed (Birchall and Kelly 1983) that the raw material for $95 \%$ of all synthetic organic chemicals was coal. In the eighties, when the production of synthetic organic chemicals increased more than a hundred fold, the raw material for some $97 \%$ is petroleum, which is scarce, expensive and depleting.

Hence, by virtue of the abundance of raw materials, the earth chemicals like silica and alumina in combination with other oxides like magnesia and alkalies are likely to predominate in human existence, overtaking metals and hydrocarbons.

\section{Energy considerations}

It is well known that different man-made materials require different levels of energy inputs. It may be useful to make some preliminary comparisons with respect to Portland cement, because it is made from two readily available constituents of the Earth's crust, viz. limestone and clay. It takes about $3 \times 10^{10}$ joules of energy to make a cubic meter of Portland Cement. It takes six times as much to make a cubic meter of polystyrene plastic and about 29 times as much to make a cubic meter of stainless steel (Birchall and Kelly 1983). Thus, Portland Cement, an inorganic material, 
has a considerable advantage in energy terms over plastics and metals. This obviously suggests that technologists should re-examine inorganic materials as replacements for energy-expensive materials.

\section{Engineering properties}

The engineering properties of competitive materials--metals, ceramics (inorganics) and rubber/and plastics (organics) in broad terms - owe their origin to their structure and chemical bonding (Watson 1975). Perhaps, their characteristic behaviour can be compared as follows:

\subsection{Metals}

Occurrence of slip in terms of non-specific and non-directional nature of metallic bond as well as the discrepancy between the estimated and measured strength due to dislocations.

\subsection{Ceramics (Inorganics)}

Brittleness and high theoretical strength due to restricted slip in ionic and covalent structures as well as the possibility of obtaining glass form but with poor resistance to crack propagation from flaws.

\subsection{Rubber and plastics (Organics)}

Long chain covalent structures involving secondary interchain bonding forces: characteristically weaker and less stiff than metals and ceramics.

Needless to mention that the above three generic groups of materials can be combined to produce composites which obviously will differ in characteristics from the individual behaviour of the constituents. Keeping this aspect aside for the time being, let us compare numerically some of the properties of the above three generic groups of materials (table 2).

It is clear that in the context of the three important engineering properties of materials, viz. stiffness (resistance to bending), tensile strength (resistance to pulling) and fracture toughness (resistance to impact), the inorganic materials are stiff but lack

Table 2. Property comparison of generic engineering materials.

\begin{tabular}{lcc}
\hline Materials & $\begin{array}{c}\text { Tensile strength } \\
\left(\mathrm{N} / \mathrm{m}^{2}\right)\end{array}$ & $\begin{array}{c}\text { Elastic modulus } \\
\left(\mathrm{N} / \mathrm{m}^{2}\right)\end{array}$ \\
\hline $\begin{array}{l}\text { Nonferrous metals/alloys } \\
\text { (Al, Cu, Brass, etc.) }\end{array}$ & $100-400 \times 10^{6}$ & $5-20 \times 10^{10}$ \\
$\begin{array}{l}\text { Glass } \\
\text { Brick/concrete }\end{array}$ & $35-70 \times 10^{6}$ & $70,000 \times 10^{6}$ \\
Polymers & $5-6 \times 10^{6}$ & \\
(PE, PP, PVC, PS, PMMA) & $10-70 \times 10^{6}$ & $100-7000 \times 10^{6}$ \\
\hline
\end{tabular}


toughness and tensile strength. It is apparent that these inadequacies of inorganic materials have restricted their application horizons so far.

\section{Combustibility and disposability}

In the materials application field, two major areas of concern today are the combustibility and environment-friendly disposability. The fire hazard of organic materials in home and public buildings cannot be ignored. On the other hand, inorganic materials, which do not burn, score an advantage.

Further, recycling, reclamation and biodegradation coupled with post-use disposal are becoming key considerations in the development of newer products. In future, this issue will transcend typical business considerations such as competitiveness, capital requirements, risk-management and profitability. The technological solution for environmental protection is being sought through integrated waste management. It will be shown later that even in this respect, the inorganic materials will tend to have an edge over other groups of man-made substances.

\section{Novel inorganic materials in race}

From the foregoing discourse, it is evident that inorganic materials enjoy certain advantages in terms of availability of raw materials, energy requirements in production, non-combustibility and environment protection but they have an inherent shortcoming in some of their engineering properties. In the following sections of this paper, we intend to highlight a few illustrations of novel approaches being made in developing and applying inorganic materials to substitute metals and plastics. The examples have essentially been drawn from the ongoing research projects of the Research and Consultancy Directorate of The Associated Cement Cos. Ltd. (ACC).

\section{Processing of common-place natural inorganic raw materials for engineering applications}

\subsection{Silica concrete}

From the abundantly occurring natural raw materials like quartzite and quartz sand, a product has been developed which is known as 'silcrete' or 'silica concrete', utilizing the polymorphic transformation properties of silica and hydrothermal processing. It is a unique building material made up of silica in the form of alpha quartz in both binder and aggregate. The product characteristics are furnished in table 3 .

As can be seen the product in the form of precast shapes can be used with advantage in lining chimneys, tunnels, induction furnaces, pickling baths, acid collectors and also as decorative facing of buildings, etc.

\subsection{Fused cast basalt}

Basalt, as a commonly occurring natural rock used in the form of road ballasts and concrete aggregates, is widely known but its value addition through fusion and casting 
Table 3. Properties of silcrete.

\begin{tabular}{lc}
\hline Properties & Values \\
\hline Density $\left(\mathrm{g} / \mathrm{cm}^{3}\right.$ ) & $1 \cdot 65-2 \cdot 30$ \\
Compressive strength $(\mathrm{MPa})$ & $60-120$ \\
Bending strength $(\mathrm{MPa})$ & $15-25$ \\
Porosity $(\%)$ & $12-40$ \\
Thermal stability (no. of cycles) & 20 \\
$\left(1200^{\circ} \mathrm{C}\right.$ - ambient) & 3 \\
Water absorption $(\%)$ & 99 \\
Acid resistance $(\%)$ & At least 1000 \\
Frost resistance (no. of cycles) & $1650^{\circ} \mathrm{C}$ \\
Refractoriness & \\
\hline
\end{tabular}

Table 4. Properties of fused-cast basait.

\begin{tabular}{lc}
\hline Properties & Values \\
\hline Density $\left(\mathrm{g} / \mathrm{cm}^{3}\right)$ & $2 \cdot 8$ \\
Water absorption $(\%)$ & $\mathrm{Nil}$ \\
Compressive strength $\left(\mathrm{N} / \mathrm{mm}^{2}\right)$ & 450 \\
Bending strength $\left(\mathrm{N} / \mathrm{mm}^{2}\right)$ & 30 \\
Wear resistance & $4-6 \mathrm{~cm}^{3} / 50 \mathrm{~cm}^{2}$ \\
Alkali resistance $(\%)$ & \\
$(10-25 \%) \mathrm{KOH}$ at $20-80^{\circ} \mathrm{C}$ & 100 \\
$(10-25 \%) \mathrm{NaOH}$ at $20-80^{\circ} \mathrm{C}$ & Almost 100 \\
$\mathrm{CaCl}$ & at $20^{\circ} \mathrm{C}$ \\
$\mathrm{Acid}$ resistance $(\%)$ & Almost 100 \\
$25 \% \mathrm{HCl}^{\circ} 20^{\circ} \mathrm{C}$. & \\
$40 \% \mathrm{H}_{2} \mathrm{SO}_{4}$ at $20^{\circ} \mathrm{C}$. & Almost 100 \\
$0.5 \% \mathrm{HNO}$ at $20^{\circ} \mathrm{C}$ & Almost 100 \\
$8 \%$ lactic at $20^{\circ} \mathrm{C}$ & Almost 100 \\
\hline
\end{tabular}

is not commonly known. Developmental attempts undertaken at our laboratories have demonstrated that it is possible to convert some of the select basalts into fused cast blocks of monophasic or diphasic composition having properties as indicated in table 4 and a microstructure of interlocked spherulites with fine acicular crystallites (Chatterjee 1975).

In addition to the high abrasion and chemicals resistance, the fused-cast basalt has a smooth sliding surface that remains unclogged even after an idle period in a wet transportation system. This is why the fused cast basalt is manufactured in the form of tiles or pipe sections for lining purposes. Straight pipes, pipe elbows or pipe fittings are supplied with a steel casing or standard precast tiles are used for various lining purposes. Pneumatic and hydraulic transport of powdered and granular bulk materials such as ash, sand, limestone, grains, etc. are finding even wider application in practice. Numerous examples are available abroad for extended life of metallic transportation systems with fused cast basalt linings. Generally, such life extensions are of the order of 10-15 times. 
Table 5. Compressive strength of metakaolin cubes.

\begin{tabular}{|c|c|c|c|}
\hline $\begin{array}{l}\text { Initial } \\
\text { atm. }\end{array}$ & $\begin{array}{l}\text { Curing } \\
\text { conditions } \\
\text { (temp }{ }^{\circ} \mathrm{C} \text { ) }\end{array}$ & $\begin{array}{l}\text { Subsequent } \\
\text { wet cure } \\
\text { duration } \\
\left(20^{\circ} \mathrm{C}\right)\end{array}$ & $\begin{array}{l}\text { Compressive } \\
\text { strength } \\
\text { (KPa) }\end{array}$ \\
\hline Sat. air & $\begin{array}{r}85 \\
125\end{array}$ & $\begin{array}{l}60 \\
60\end{array}$ & $\begin{array}{r}90-100 \\
130-170\end{array}$ \\
\hline Water & $\begin{array}{r}85 \\
125\end{array}$ & $\begin{array}{l}60 \\
60\end{array}$ & $\begin{array}{r}95-110 \\
185-265\end{array}$ \\
\hline
\end{tabular}

\subsection{Metakaolin-based cement}

Metakaolin is an essentially anhydrous aluminium silicate which is derived from the commonly occurring clay mineral kaolin having the ideal formula $\mathrm{Al}_{2} \mathrm{Si}_{2} \mathrm{O}_{5}(\mathrm{OH})_{4}$. It is reported that this mineral form allows alkali-activated zeolite or amorphous zeolite precursor formation to occur at reasonable rates even at room temperature. It appears from the scanty information available that a cement named 'Pyrament' has been introduced into the US market based on this concept. Exploratory investigations of similar systems in our laboratories and elsewhere (Palomo and Glasser 1992) have shown that mixes of metakaolin, kaolin, silica, lime, etc activated with sodium hydroxide or sodium silicate with proper mixing and dispersion in aqueous medium have reasonable workability and setting properties to give products having good compressive strengths (table 5).

An amorphous gel phase develops in the hydrated mass and a high content of gel is associated with the high cube compressive strengths. Thus, the system offers potential to develop dense, strong and stable shapes of aluminosilicate gel which is being explored quite extensively by the scientific community.

\subsection{Advanced ceramics}

One of the most spectacular developments in the field of inorganic materials has been the growth of advanced ceramics. Today these materials have shown the potential of serving such diverse functional fields as thermal, mechanical, biochemical, electromagnetic, optical and nuclear. On a global perspective, it appears that of all the functional areas, electro-ceramics dominates with a market share of about $70 \%$ followed by structural or mechano-ceramics. The basic materials which are used in the manufacture of advanced ceramics are alumina, zirconia, titanates, ferrites, etc in the oxide family constituting $88-90 \%$ and silicon carbide, silicon nitride, boron carbide, boron nitride, etc in the nonoxide family in smaller proportions.

ACC in its advanced ceramics development programme have concentrated their efforts in ceramics powders like alumina, zirconia and barium titanate by upscaling the following manufacturing processes to pilot production level: hydrothermal, precipitation and co-precipitation and sol-gel. The properties of powders developed at ACC laboratories are briefly summarized in table 6 (Page and Chatterjee 1990; Page et al 1991, 1992). 
Table 6a. Properties of ceramic powders developed by ACC.

\begin{tabular}{lcccc}
\hline Property & \multicolumn{2}{c}{$\mathrm{Al}_{2} \mathrm{O}_{3}$} & \multicolumn{2}{c}{$\mathrm{ZrO}_{2}$} \\
\hline $\mathrm{SiO}_{2}$ & 0.07 & 1.030 & 0.001 & 1.200 \\
$\mathrm{Fe}_{2} \mathrm{O}_{3}$ & 0.03 & 0.015 & 0.019 & 0.317 \\
$\mathrm{TiO}_{2}$ & - & - & 0.141 & 0.080 \\
$\mathrm{CaO}$ & - & - & 0.010 & $2 \cdot 103$ \\
$\mathrm{MgO}$ & - & - & - & $1 \cdot 146$ \\
$\mathrm{SO}_{3}$ & - & - & 0.001 & 0.110 \\
$\mathrm{Na}_{2} \mathrm{O}$ & 0.10 & 0.008 & 0.017 & 0.020 \\
$\mathrm{Al}_{2} \mathrm{O}_{3}$ & 99.8 & 99.9 & - & - \\
$\mathrm{Avg}_{3}$ particle & & & & \\
size $(\mu \mathrm{m})$ & 0.7 & 0.5 & $\%<5 \mu \mathrm{m}$ & $\%<5 \mu \mathrm{m}$ \\
& - & - & 92.0 & 30.0 \\
$\mathrm{~d}_{50}$ & - & - & 2.6 & 8.2 \\
$\mathrm{ZrO}_{2}+2 \% \mathrm{HfO}_{2}$ & - & - & 99.81 & 95.03 \\
\hline
\end{tabular}

Table 6b. Properties of barium titanate.

\begin{tabular}{lc}
\hline $\mathrm{BaO}+\mathrm{SrO}_{2}$ & $34 \cdot 0-34 \cdot 8$ \\
$\mathrm{TiO}_{2}$ & $65-0-65 \cdot 8$ \\
Others & 0.2 \\
Mole ratio & \\
BaO: $\mathrm{TiO}_{2}$ & $0.97-1.02$ \\
Average particle size & $1-3 \mu \mathrm{m}$ \\
\hline
\end{tabular}

The intended application areas for the powders developed are as follows:

Alumina: electronic, catalytic and coating

Barium titanate: electronic

Zirconia: coating and structural

In addition, the perspective plans of ACC in this area include the development of ceramic membranes for separation processes in the chemicals industry, filters for hot gas cleaning and molten metal processing and phosphatic materials for cement and bioceramics applications.

\section{Processing of inorganic industrial wastes for environmental protection}

Although recycling and reprocessing of steel scrap, aluminium cans, glass cullet, waste paper and some forms of plastic are in practice today, the possibilities of value addition to a large variety of inorganic industrial wastes are opening up newer opportunities. A few such approaches are mentioned here to illustrate the possibilities.

\subsection{Alkali-activated multiblend cements}

The alkali-activated slag cements are formed by combining ground-granulated slag with alkaline chemicals in liquid form or intergrinding stag with less hygroscopic alkaline chemicals. Glukhovskii of Kiev Institute of Civil Engineering in the former 
USSR is regarded as the pioneer in developing this binder. Following his path, numerous studies have been carried out in various countries including our own laboratory in India on alkali activated cement and concrete (Parameswaran and Chatterjee 1986). This concept has now been revived for the possibilities of recycling industrial wastes in multiblend formulations such as:

$$
\begin{aligned}
& \text { blast furnace slag + fly ash } \\
& \text { blast furnace slag + fly ash + cement kiln dust } \\
& \text { blast furnace slag + electrophosphorous slag. }
\end{aligned}
$$

Such blends, when properly formulated, seem to have good potential to stabilize toxic metals and radioactive wastes of low and intermediate levels.

\subsection{Fly-ash cement and building materials}

The disposal of fly ash generated by the coal-fired thermal power plants has been a major concern in all countries when power is generated by this process route. The situation is graver in a country like India where high ash coal is used for power generation. Certain technologies for utilization of fly ash are already in practice such as its use as a pozzolanic material in making Portland Pozzolana cement or its use in making bricks, etc. (ACC 1992). Since these technologies can help dispose only a very small fraction of fly ash generated in the country, more extensive avenues of recycling and value addition are essential.

One of the possibilities explored by us in association with the Materials Research

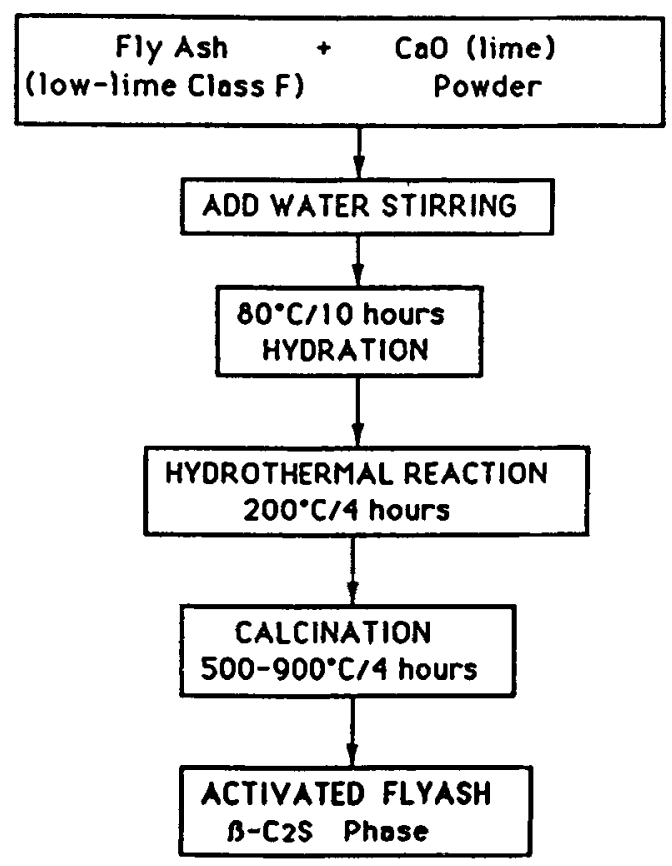

Figure 1. Flow chart of the general procedure of hydrothermal processing of fly ash. 


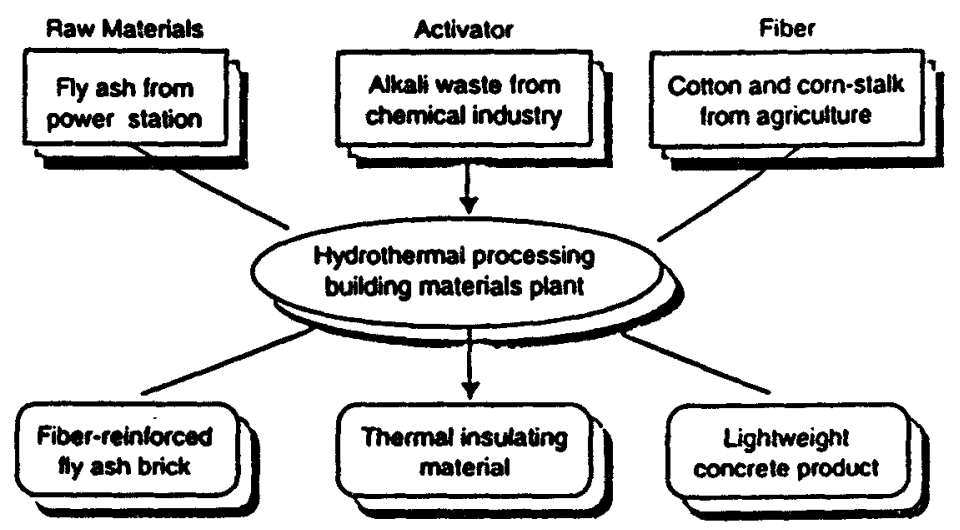

Figure 2. Hydrothermally processed building materials plant-A possibility.

Laboratory of Pennsylvania State University, USA is to produce an activated fly ash cement by hydrothermal treatment (figure 1).

The reaction products generated through such a process are $\beta 2 \mathrm{CaO} \cdot \mathrm{SiO}_{2}, 12 \mathrm{CaO}$, $7 \mathrm{Al}_{2} \mathrm{O}_{3}$ and $\mathrm{CaCO}_{3}$. These binders are slow and moderate in developing strengths. For example, one may expect about $40 \mathrm{MPa}$ strength in about 90 days from a level of $5 \mathrm{MPa}$ in 3 days.

The technology can be further extended to produce formed cementitious composites by two-stage thermal processing (figure 2). Possibilities of using processed renewable natural fibres with fly ash and waste alkalies in such composites make the process and product potential from the point of view of wastes recycling and environmental protection.

\section{Biomimic composites from inorganic primaries}

The basic shortcoming of inorganic materials in respect of their toughness has already been discussed. The issue before the scientists, therefore, centres around the search for technology to make sufficiently tough inorganic materials at low temperature. Living organisms apparently provide instances where it is possible to harness inorganic materials and yet achieve remarkable improvements in the above properties. It is reported that the abalone shell is made up of $99 \%$ calcium carbonate but with tensile strength of over $100 \mathrm{MPa}$ and toughness of $1000 \mathrm{~J} / \mathrm{m}^{2}$, which are quite comparable to polystyrene and plexiglass (Birchall and Kelly 1983). Microstructurally, the shell is made up of flat plates of calcium carbonate, each about $0.2 \mu \mathrm{m}$ thick but stacked with remarkable uniformity with a thin separating layer of protein. Apparently, this unique microstructure is responsible for improved toughness.

Another example is the calcified vertebrate tissue. The range of properties of human bones is shown in table 7 (Brown 1990). With reference to table 7 , one may consider specifically the following points.

(a) The mineral fraction, which is essentially impure calcium deficient hydroxyapatite, varies, depending on biological formation. 
Table 7. Miscellaneous properties of hard tissues.

\begin{tabular}{lccc} 
& & \multicolumn{2}{c}{ Bone } \\
\cline { 3 - 4 } Property & Enamel & Cancellous & Compact \\
\hline Fraction of mineral $(\%)$ & $92-97$ & 60 & 60 \\
Density $\left(\mathrm{g} / \mathrm{cm}^{3}\right)$ & 3 & $1 \cdot 5$ & $2 \cdot 2$ \\
Strength $(\mathrm{MPa})$ & & & \\
$\quad$ Compressive & $250-400$ & 140 & 300 \\
$\quad$ Bending & & 100 & 200 \\
$\quad$ Tensile & & 20 & 167 \\
Young's modulus (GPa) & $40-84$ & 10 & 22 \\
Fracture toughness & & & $15 \cdot 9$ \\
$\quad$ (MPam & & $2 \cdot 2$ & ) \\
\hline
\end{tabular}

(b) Bone contains up to $40 \%$ organic matter (collagen) giving fracture toughness up to almost $16 \mathrm{MPa} \mathrm{m}^{1 / 2}$, despite the presence of high flaws (small pores, canals, etc.) (c) By sequencing amino acid residues along the polypeptide chains and controlling the chemical and thermal environment during crosslinking and mineralization the bone properties are varied as required in different parts of the body.

The above examples of abalone shell, human bone, etc. have now induced the scientists to think about biomimic composites with inorganic mineral phases. This has led to scientific research in the new field of chemically bonded ceramics (CBC). Some illustrations are given below.

\subsection{Low temperature formation of hydroxyapatite}

Researches have established that (a) the acidic and basic reactants can be manipulated in the synthesis of hydroxyapatite as indicated below:

$$
\begin{array}{r}
6 \mathrm{CaHPO}_{4}+6 \mathrm{Ca}_{4}\left(\mathrm{PO}_{4}\right)_{2} \mathrm{O} \rightarrow 3 \mathrm{Ca}_{10}\left(\mathrm{PO}_{4}\right)_{6}(\mathrm{OH})_{2} \\
\text { (stochiometric) } \\
6 \mathrm{CaHPO}_{4}+3 \mathrm{Ca}_{4}\left(\mathrm{PO}_{4}\right)_{2} \mathrm{O} \rightarrow 2 \mathrm{Ca}_{9}\left(\mathrm{HPO}_{4}\right)\left(\mathrm{PO}_{4}\right)_{6} \mathrm{OH} \\
\text { (calcium-deficient). }
\end{array}
$$

(b) Calcium phosphate product with porosities of 50-80\%, compressive strengths up to $35 \mathrm{MPa}$ and tensile strength of 3.5 MPa are possible to synthesize for biorestoration of tissues (Chatterjee 1992).

\subsection{Macro defect-free cement}

In order to overcome the problems of low tensile strength and toughness in cementitious systems, macro defect-free (MDF) cements have been developed on the basis of hydraulic cements, water-soluble polymers and high shear mixing about a decade back by Birchall and coworkers at ICI Mont Division. The product showed that the 
Table 8. Properties of MDF cements.

\begin{tabular}{lc}
\hline Properties & Values \\
\hline Compressive strength & $300 \mathrm{MPa}$ \\
Flexural strength & $150-200 \mathrm{MPa}$ \\
Young's modulus & $50 \mathrm{GPa}$ \\
Porosity & $1 \%$ \\
\hline
\end{tabular}

maximum diameter of pores in cement can be reduced from the usual millimeter or so to no more than a few micrometers. Tested in bending, this product showed a strength of $150 \mathrm{MPa}$ and more which is quite comparable to that of aluminium. The fracture toughness of MDF cement is also notable. Some interesting properties of this product are given in table 8 .

The product, despite substantial improvements in its properties, could not catch up in actual application due to its durability problem on account of the presence of water-soluble polymers in the system. Hence, the current research centres around the insolubilization of polymer matrix in MDF cement for assured durability along with further particle or fibre reinforcement possibilities.

Thus, several attempts are being made to produce biomimic composites based on inorganic minerals and organic modifiers.

\section{Conclusion}

From the information and data presented above, one would prefer to indicate that there are many facilitators in the race of inorganic materials.

(i) ever increasing possibilities of manipulating the inorganic chemical compounds at low temperatures.

(ii) advances in the understanding of structure-property relationship of materials.

(iii) amenability of inorganic materials to complex processing.

(iv) abundance of starting raw materials in nature.

(v) friendliness to environment.

Some of the shortcomings of inorganic materials such as high energy of production as in the case of the high-fired ceramics or the brittleness of materials are possible to be manipulated through production of chemically bonded ceramics or following the biomimic composites route. Thus, perhaps, a new era of inorganic materials is being ushered in for engineering applications, energy conservation and environmental protection. It may not be too premature to say that an ultra-neolithic age is in the offing.

\section{References}

ACC 1992 Indian Concrete J. 66359

Birchall J D and Kelly A 1983 New inorganic materials (Scientific American)

Brown P W 1990 in Advances in cementitious materials (ed.) Sidney Mindess (Ohio, USA: Am Ceram. Soc.); also in Ceram. Trans. 16769 
Chatterjee A K 1975 Cast rock products - substitutes for iron and steel (Science Reporter)

Chatterjee A K 1992 Special and new cements, 9 th Int. congress on the chemistry of cement, congress reports (New Delhi: NCB) Vol. 1

Page C H and Chatterjee A K 1990 Comparative evaluation of alumina powders obtained from different process routes for engineering applications, Int. symp. on advanced ceramics-IASC 90, BARC, Bombay, India

Page C H, Thombare C H, Varadarajan V, Borkar S A and Chatterjee A K 1991 Characterization and sintering behaviour of barium titanate powders obtained by various synthetic routes, Proc. of 5 th int. symp. on the science and technology of sintering (Sintering '91) pp. 319-325

Page C H, Bhattacherjee S, Thombare C H, Varadarajan V and Chatterjee A K 1992 Experiences of extracting zirconia from Indian zircon sand and its characterization. Proc. of the int. ceramic conf. Australia (Austceram-92) vol. 2, pp. 1166-72

Palomo A and Glasser F P 1992 Br. Ceram. Trans. J. 91107

Parameswaran P S and Chatterjee A K 1986 Alkali activation of Indian blast furnace slag, 8th int. congress on the chemistry of cement, Rio de Janeiro, Brazil, Vol. IV

Rankama K and Sahama Th G 1964 Geochemistry (Chicago: The University of Chicago Press)

Watson K L 1975 Materials in chemical perspective (New York: John Wiley and Sons) 